\title{
GMR
}

\section{Selection of maize inbred lines and gene expression for resistance to ear rot}

\author{
G.S. Pereira' ${ }^{1}$, R.G.V. Pinho ${ }^{2}$, E.V.R.V. Pinho' ${ }^{2}$ L.P.M. Pires ${ }^{2}$, \\ L.A.Y. Bernardo Junior ${ }^{1}$, J.L.A. Pereira ${ }^{3}$ and M.P. Melo ${ }^{4}$ \\ ${ }^{1}$ Programa de Pós-Graduação em Genética e Melhoramento de Plantas, \\ Universidade Federal de Lavras, Lavras, MG, Brasil \\ ${ }^{2}$ Programa de Pós-Graduação em Fitotecnia, Universidade Federal de Lavras, \\ Lavras, MG, Brasil \\ ${ }^{3}$ Departamento de Agronomia, Instituto Federal do Sul de Minas, \\ Pouso Alegre, MG, Brasil \\ ${ }^{4}$ Departamento de Fitotecnia, Universidade Federal do Piauí, Teresina, PI, Brasil \\ Corresponding author: R.G.V. Pinho \\ E-mail: renzovonpinho@gmail.com \\ Genet. Mol. Res. 16 (3): gmr16039415 \\ Received October 6, 2016 \\ Accepted May 8, 2017 \\ Published July 6, 2017 \\ DOI http://dx.doi.org/10.4238/gmr16039415 \\ Copyright $(2017$ The Authors. This is an open-access article distributed under the terms of \\ the Creative Commons Attribution ShareAlike (CC BY-SA) 4.0 License.
}

\begin{abstract}
In recent years, there has been a large incidence of fungi causing "ear rot" in maize in Brazil, the main fungus being Fusarium verticillioides. The most efficient and competitive alternative for control of this disease consists of using maize hybrids resistant to this pathogen. Thus, the aims of this study were to analyze the genetic variability of maize inbred lines in regard to resistance to ear rot to observe if there is a maternal effect to resistance to ear rot, to study genetic control of the traits evaluated in hybrids originating from inbred lines of the maize breeding program at the Agriculture Department of Universidade Federal de Lavras (Lavras, MG, Brazil), and characterize the gene expression pattern related to the plant defense mechanism against $F$. verticillioides. High genetic availability was observed for resistance to this disease among the inbred lines evaluated. Considering combined
\end{abstract}


diallel analysis, it was observed that the mean square of general combining ability (GCA) was not significant for the characteristic under study. However, specific combining ability (SCA) was significant, which indicates the predominance of non-additive effects involved in control of the characteristic for the population evaluated. A maternal effect was not observed for the characteristic of ear rot resistance in this study. Inbred lines 22, 58, and 91 showed potential for use in breeding programs aiming at resistance to $F$. verticillioides. Only two genes, LOX8 and Hsp82, had a satisfactory result that was able to be related to a plant defense mechanism when there is ear rot infection, though expression of these genes was observed in only one susceptible genotype. Thus, the genes LOX8 and Hsp82 are potential molecular markers for selection of maize inbred lines resistant to $F$. verticillioides.

Key words: Diallel; RT-qPCR; Genetic variability; SCA; GCA

\section{INTRODUCTION}

The increase in maize cultivation in the no-tillage system, the lack of crop rotation and succession, and favorable climatic conditions are among the most relevant causes of the high incidence of pathogens that cause ear rot (Casa et al., 2006), such as Fusarium verticillioides, Fusarium graminiareaum, Gibberella zeae, Diplodia maydis, and Diplodia macrospora. Among them, $F$. verticillioides stands out from the other fungi that cause ear rot due to its wide occurrence throughout the world and because it produces mycotoxins of the fumonisin group (van Egmond et al., 2007; Reid et al., 2009). It is a fungus that can damage the quality of products, leading to loss of yield and nutritional value of the kernels, as well as reducing their palatability to animals (Silva et al., 2007).

The most efficient control method for this disease consists of the use of hybrids resistant to $F$. verticillioides; thus, maize breeding programs throughout the world have invested resources aiming to obtain genetic gain for resistance to this and to other fungi of the ear rot complex. In the literature, heritability of resistance to the symptoms caused by Fusarium spp and manifested in kernels is estimated to be of medium to high magnitude (Robertson et al., 2006; Martin et al., 2012), showing that there is correspondence between the phenotypic value and genetic value, which facilitates gain from selection. However, genetic control and the mechanisms of plant resistance to this fungus have not yet been fully explained. Some studies have also indicated the presence of a maternal effect in resistance to ear rot (Kovács et al., 1994; Mukanga et al., 2010). Diallel analysis may be an alternative for studying genetic inheritance of characteristics that are controlled both by nuclear genes and maternal or extrachromosomal inheritance.

In addition, identification of genes related to resistance to ear rot through quantitative analysis of the gene expression profile may be effective for developing functional markers for use in the process of selecting superior genotypes for such a characteristic. It should be borne in mind that evaluation of the percentage of ear rot constitutes an important difficulty in carrying out maize breeding programs because of the time necessary for evaluation of all the progenies before selection of the best. Thus, knowledge and use of markers can facilitate evaluation of plant resistance to $F$. verticillioides.

Genetics and Molecular Research 16 (3): gmr16039415 
In general, the plant defense system is associated with an increase in the activity of proteins related to pathogenesis (PR) and to other defense processes such as oxidative burst, phytoalexin accumulation, lignification, and cell wall stiffening (Durrant and Dong, 2004). Nevertheless, PR are detected due to their accumulation in plants under the action of some biotic stress and not necessarily for their antipathogenic action. Real time PCR has been very effective in studies for identification of genes of resistance to biotic and abiotic stresses.

Up to now, there have not been a large number of studies in the literature for the purpose of analyzing inheritance of the disease using genotypes developed in Brazil. Thus, the aims of this study were to evaluate the reaction of maize inbred lines originating from the germplasm bank of the Agriculture Department of Universidade Federal de Lavras (UFLA) when inoculated with $F$. verticillioides, to observe if there is a maternal effect for resistance to ear rot, to study genetic control of this characteristic and the correlation of the traits studied, and to characterize the gene expression pattern related to the plant defense mechanism against the aforementioned pathogenic agent.

\section{MATERIAL AND METHODS}

This study was carried out in different steps. In the first step, screening was carried out for selection of the four most susceptible and the four most resistant inbred lines, which were used in obtaining hybrid and reciprocals. Subsequently, these genotypes were evaluated together with the inbred lines in a partial diallel arrangement in two regions of the south of Minas Gerais, Brazil. Finally, the aforementioned inbred lines were also evaluated in regard to gene expression for response to infection by $F$. verticillioides.

\section{Screening of the inbred lines}

In this step, 30 elite inbred lines from the maize active germplasm bank of UFLA were evaluated in relation to infection from $F$. verticillioides. The experiment was conducted in completely randomized blocks with three replications and 30 treatments in an experimental area of the Agriculture Department of UFLA in the 2011/2012 crop season. Each plot consisted of two 5-m rows at a spacing of $0.8 \mathrm{~m}$, and each row consisted of 20 plants.

At sowing, $400 \mathrm{~kg} / \mathrm{ha}$ of formula $8(\mathrm{~N}): 28\left(\mathrm{P}_{2} \mathrm{O}_{5}\right): 16\left(\mathrm{~K}_{2} \mathrm{O}\right)$ were used. Later, 300 $\mathrm{kg} / \mathrm{ha}$ of formula $30(\mathrm{~N}): 00\left(\mathrm{P}_{2} \mathrm{O}_{5}\right): 20\left(\mathrm{~K}_{2} \mathrm{O}\right)$ was applied in the fully expanded 4-5 leaf stage. The control of the invasive plants was done with the herbicide Primestra Gold (atrazine + metalaclor) in the dosage of $4 \mathrm{~L} / \mathrm{ha}$ of commercial product, applied in pre-emergence. The other crop and plant health treatments were undertaken at suitable periods according to recommendations for the crop.

The inoculum of the fungus came from the mycology collection of Embrapa Milho e Sorgo, and it was replicated in the mycology laboratory of the Plant Pathology Department of UFLA. The isolates were grown in a complete medium for seven days before inoculation. The suspension of fungus conidia was adjusted through counting in a Neubauer chamber to $10^{6}$ conidia $/ \mathrm{mL}$ at the time of inoculation. Inoculations of the pathogen were carried out 15 days after $100 \%$ of the plants of the plot had developed style-stigmas in the field. A pipette was used for inoculation of $1 \mathrm{~mL}$ of the suspension obtained, in the central region of each ear, as proposed by Clements et al. (2003). The monthly mean temperatures and relative humidities of the 2011/2012 crop season are shown in Figure 1.

Genetics and Molecular Research 16 (3): gmr16039415 


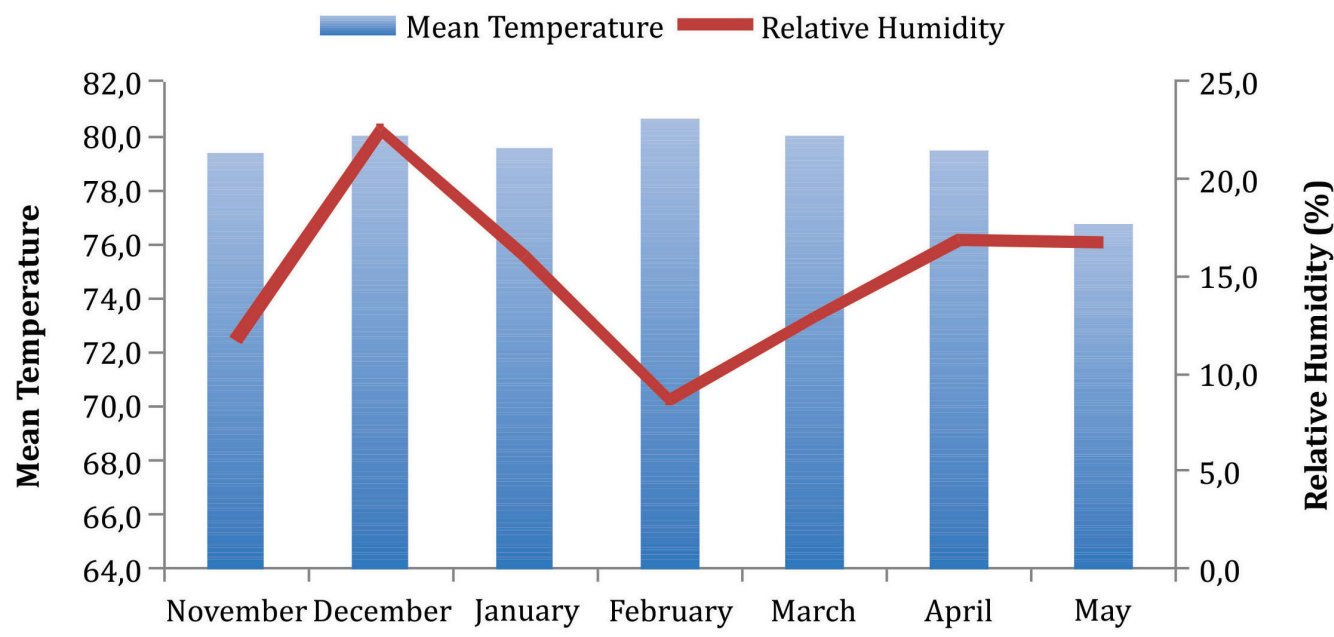

Figure 1. Mean temperatures and relative humidities for the months of October 2011 to April 2012.

The incidence of kernel damage was determined according to the procedure proposed by directive No. 11 of April 12, 1996 (Brasil, 1996). In a 300-g sample per plot, kernels were visually separated and the percentage of kernels with discoloration symptoms in more than one-fourth of the total surface area was determined. The data obtained were subjected to analyses of variance by the R software. The mean values were grouped by the Scott-Knott test at $5 \%$ probability using the Genes program.

Broad sense heritability $\left(\mathrm{h}^{2}\right)$ in the mean of the cultivars was estimated using the expression cited by Ramalho et al. (2012):

$$
h_{m}^{2}=\left(\sigma_{g}^{2} / \sigma_{f}^{2}\right) \times 100
$$

(Equation 1)

where $\mathrm{h}_{\mathrm{m}}^{2}$ is the estimated mean heritability, $\sigma_{\mathrm{g}}^{2}$ corresponds to genetic variance among the inbred lines, and $\sigma_{\mathrm{f}}^{2}$ is phenotypic variance among the inbred lines estimated from the mean squares obtained.

Selective accuracy $\left(\mathrm{r}_{\mathrm{gg}}\right)$ was also estimated as a measure of experimental precision according to the expression proposed by Cargnelutti Filho and Storck (2009):

$$
r_{g g}=\sqrt{1-\frac{1}{F c}}
$$

in which $\mathrm{Fc}$ is the value of the $\mathrm{F}$ test for the effect of inbred lines associated with analysis of variance.

The field for production of hybrid cross seeds was composed of eight blocks of four 10-m rows, and each block consisted of 160 plants. One of the selected inbred lines was sown in each block. To prevent undesired crosses, the ears were protected with plastic bags before 
development of the style-stigmas. When the stigmas were receptive, self-pollinations and the desired crosses were performed manually. The hybrids and their reciprocals were obtained through a partial diallel cross between two groups of inbred lines, with one group composed of inbred lines 22, 37, 58, and 91, resistant to the disease, and another composed of inbred lines $40,64,81,83$, susceptible to the disease. After harvest, the ears were dried and manually shelled and the seeds were cleaned and classified in regard to physical and health quality, eliminating those with visual signs of kernel damage.

\section{Diallel analysis}

In this step, two experiments were conducted, one in the experimental area of the Technology Development Center in Agriculture of UFLA, in the municipality of Lavras, MG, and the other in Instituto Federal do Sul de Minas in Inconfidentes, MG. The experiments were planted at the end of November 2013.

The climate of both municipalities is classified as mesothermic. In Table 1, the climate characteristics and geographical coordinates of each municipality are shown.

Table 1. Altitude, latitude, longitude, and climate characteristics of the municipalities of the south of Minas Gerais, Brazil - Inconfidentes and Lavras.

\begin{tabular}{l|c|c|c|c|c}
\hline Location & Altitude & Latitude & Longitude & Mean annual temperature $\left({ }^{\circ} \mathrm{C}\right)$ & Mean annual rainfall \\
\hline Inconfidentes & $1150 \mathrm{~m}$ & $22^{\circ} 19^{\prime} \mathrm{S}$ & $46^{\circ} 19^{\prime} \mathrm{W}$ & 19.2 & 1400 to $1800 \mathrm{~mm}$ \\
\hline Lavras & $919 \mathrm{~m}$ & $21^{\circ} 75^{\prime} \mathrm{S}$ & $45^{\circ} \mathrm{W}$ & 19.3 & $1411 \mathrm{~mm}$ \\
\hline
\end{tabular}

Evaluation was made of 40 maize genotypes, consisting of 16 single hybrids and their reciprocals, and eight inbred lines that gave rise to these hybrids by means of the partial diallel arrangement. The mean temperatures and monthly rainfall amounts of the 2013/2014 crop season in Lavras, MG are shown in Figure 2.

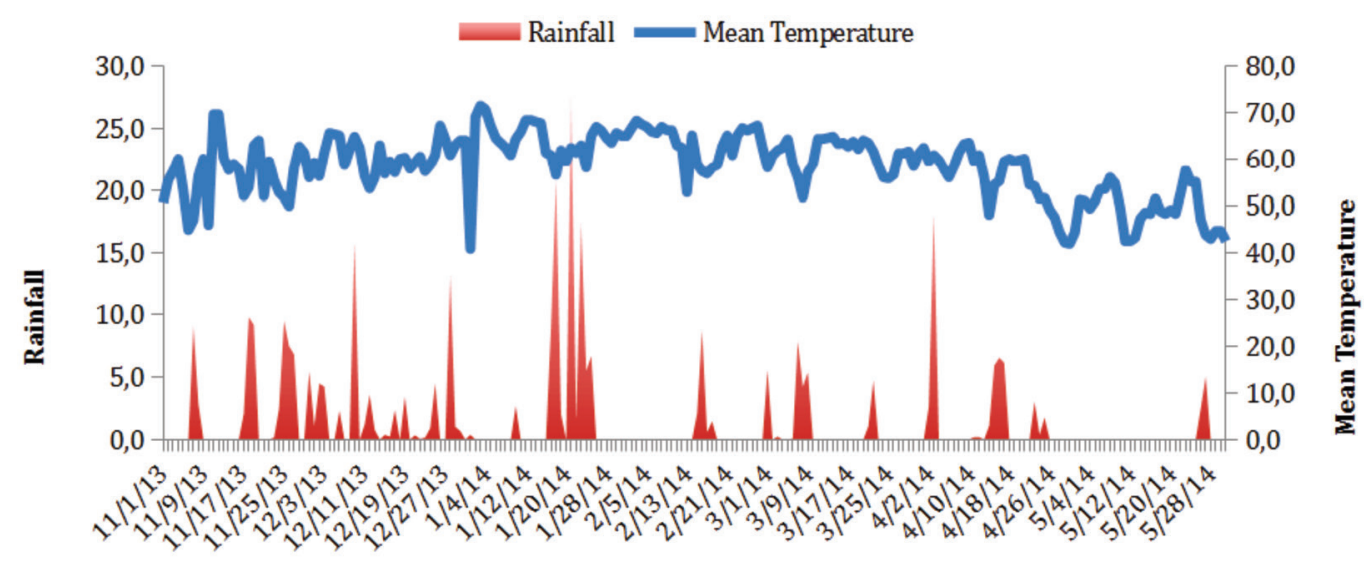

Figure 2. Mean temperatures and monthly rainfall of the 2013/2014 crop season in Lavras, MG, Brazil.

Genetics and Molecular Research 16 (3): gmr16039415 
The experiments were carried out in a randomized block design with three replications. Each plot consisted of two 4-m rows at a spacing of $0.6 \mathrm{~m}$, and each plot consisted of 32 plants. All crop and plant health treatments were performed at suitable periods according to crop needs, as previously mentioned. The same inoculum of $F$. verticillioides from the mycology collection of Embrapa Milho e Sorgo mentioned in the previous step was used. Replication, growing procedures, and inoculation of the pathogen were also carried out as described above, and the following characteristics were evaluated: percent of diseased ears - all the ears and the number of diseased ears from each plot were counted to determine the percentage; percentage of damaged kernels - the incidence of damaged kernels was determined according to the procedure proposed by directive No. 11 of April 12, 1996 (Brasil, 1996); and grain yield - ears were manually harvested for determination of grain yield per hectare. The ears were shelled, the kernels were weighed, and then samples were taken for determination of moisture content. The grain yield data were corrected to $13 \%$ moisture and expressed in $\mathrm{kg} / \mathrm{ha}$. All the statistical and genetic analyses were carried out with the assistance of the Genes computational program (Cruz, 2013).

Initially, individual analysis of variance per location was carried out. The homogeneity of the residues was verified by the Hartley test. Pimentel-Gomes (2000) comments on the use of the maximum $\mathrm{F}$ test and concludes that if the ratio between the highest and lowest residual mean square is less than seven, combined analysis can almost always be carried out without problems. However, when this ratio goes much beyond this, it is appropriate to separately consider subgroups of experiments with not very heterogeneous residual mean squares.

After that, combined analysis of variance was carried out involving the two locations, using the following statistical model:

$$
Y i j k=m+t i+a k+b(k) j+(t a) i k+\bar{e}(k) i j \quad \text { (Equation 3) }
$$

in which $Y_{i j k}$ is the observation of genotype $\mathrm{i}$ in block $\mathrm{j}$ within location $\mathrm{k}$; $\mathrm{m}$ is the overall mean; ti corresponds to the effect of genotype $i, i=1,2, \ldots, 40$; ak is effect of location $k, k=$ 1,$2 ; b_{(k) j}$ is the effect of block $\mathrm{j}$ within location $\mathrm{k}, \mathrm{j}=1,2,3$; (ta)ik corresponds to the effect of interaction between the genotypes $\mathrm{i}$ and the locations $\mathrm{k}$; and $\mathrm{e}(\mathrm{k}) \mathrm{ij}$ is the experimental error. Individual diallel analysis was carried out using method 2 of Griffing (1956). Through this methodology, the values of the effects of general and specific combining abilities were determined. This method is characterized by the inclusion of the paternal inbred lines and of all the F1 hybrids resulting from the crosses, two by two and the reciprocals. The statistical model used was:

$$
Y i j=m+g i+g j+s i j+\bar{e} i j
$$

(Equation 4)

in which Yij is the observation of the hybrid combination involving the parents $i$ and $j ; m$ is the overall mean; $g_{i}$ and $g_{j}$ correspond to the general combining ability of the $i$-th and $j$-th parent, respectively; and sij is the specific combining ability for the crosses between the parents.

After that, combined diallel analysis was carried out involving the two locations, considering all the effects as fixed, except for the genotypes and the experimental error,

Genetics and Molecular Research 16 (3): gmr16039415 
assuming the same restrictions as individual diallel analysis. The statistical model adopted was the following:

$$
Y i j=m+g i+g j+s i j+a k+g a i k+g a j k+s a i j k+\bar{e}(k) i j \quad \text { (Equation 5) }
$$

where Yij is the observation of the hybrid combination involving the parents $\mathrm{i}$ and $\mathrm{j} ; \mathrm{m}$ is the overall mean; gi and gj are general combining ability of the $\mathrm{i}$-th and $\mathrm{j}$ - th parent, respectively; $\mathrm{s}_{\mathrm{ij}}$ corresponds to specific combining ability for the crosses between the parents of order $\mathrm{i}$ and $\mathrm{j}$; ak is the effect of environment $\mathrm{k}$; gaik and gajk are the effects of interaction between general combining ability (GCA) associated with the $\mathrm{i}$ and $\mathrm{j}$-th parent with environment $\mathrm{k}$, respectively; saijk is the effect of interaction between specific combining ability (SCA) associated with parents $i$ and $j$ and with the environment $k$; and, finally, $\overline{\mathrm{e}}(\mathrm{k}) \mathrm{ij}$ corresponds to mean experimental error.

\section{Characterization of the gene expression pattern}

Eight maize inbred lines numerically denominated as $22,37,58,91,40,64,81$, and 83 were evaluated, with the first four previously selected as resistant and the following four susceptible to $F$. verticillioides in regard to gene expression for response to infection from this pathogen. At $48 \mathrm{~h}$ after the period of inoculation, three replications were collected from each inbred lines. The material collected was stored in liquid nitrogen and conserved in a freezer at $-80^{\circ} \mathrm{C}$. Primers were developed in the Department of Plant Pathology of Kansas State University, Manhattan, KS, USA.

For analysis of gene expression by the qRT-PCR technique, the target genes chosen for primer design were those associated with the plant defense mechanism against pathogenicities in general and also genes that codify some respiration enzymes and heat shock proteins. A total of 18 target genes were selected to design the primers.

The primers used were designed using the Beacon Designer software after the search for gene sequences in the database of the NCBI (National Center of Biotechnology Information). The endogenous controls used were ubiquitin and ADH (alcohol dehydrogenase). To ensure the stability of the primers during the reaction cycles, some parameters were considered, such as size of the oligonucleotide, which ranged from 18 to $20 \mathrm{bp}$, and percentage of CG, from 30 to $50 \%$, and those with high capacity for dimer formation were eliminated.

For RNA extraction, the seed tissues in maize formation were macerated in liquid nitrogen with addition of the reagent Pure Link RNA Plant ${ }^{\mathbb{B}}$ (Invitrogen). RNA integrity was checked in 1\% agarose gel. Quantification of the RNA was performed in a spectrophotometer, using wavelengths of 260 and $280 \mathrm{~nm}$. After extraction of nucleic acids, the samples were treated with DNase to avoid any contamination with DNA. For that purpose, DNase Turbo Free (Ambion) was used and the protocol carried out according to manufacturer recommendations. After this treatment, the presence of DNA was verified in 1\% agarose gel. After the RNA extraction and purification process, synthesis of cDNA was performed. To do so, the High Capacity cDNA Reverse Transcription cDNA $^{\circledR}$ kit from Applied Biosystems was used, following the protocol recommended by the manufacturer.

Genetics and Molecular Research 16 (3): gmr16039415 
For analysis of quantitative gene expression by qRT-PCR, the ABI PRISM 7500 RealTime PCR (Applied Biosystems) device was used and the SYBR Green detection system. Programming for analysis was $2 \mathrm{~min}$ at $50^{\circ} \mathrm{C}$ and $10 \mathrm{~min}$ at $95^{\circ} \mathrm{C}$, followed by 40 cycles of $15 \mathrm{~s}$ at $95^{\circ} \mathrm{C}$ and $1 \mathrm{~min}$ at $60^{\circ} \mathrm{C}$, and finishing with $15 \mathrm{~s}$ at $95^{\circ} \mathrm{C}$. Each reaction used $1.0 \mu \mathrm{L}$ cDNA diluted 1:5, $0.2 \mu \mathrm{L}$ of each primer, and 5.0 $\mu \mathrm{L}$ Master Mix SYBR green UDG with ROX (Invitrogen) for a final volume of $10.0 \mu \mathrm{L} /$ sample. The negative controls and the melting curves were included in all analyses.

Three biological replications in three technical replicates were used for each gene under study, with results normalized using the threshold cycle $(\mathrm{Ct})$ obtained by the expression of the reference genes ubiquitin and $\mathrm{ADH}$.

In this study, the comparative Ct method was used. Thus, a previous experiment of oligonucleotide validation was carried out to select those whose efficiency of amplification of the target gene and reference gene were similar and very near 100\% (Tyagi et al., 1998). The cDNAs were diluted at 1:5, 1:25, 1:125, 1:625, and 1:3125 to generate the standard curves. This procedure also allowed definition of the best dilution for each reaction.

Random samples were used as calibrators and the method used to measure relative expression was the Relative Standard Curve Method, described in the manual of the device (Applied Biosystems). For quantification of gene expression by the real time PCR technique, the values obtained corresponding to the levels of mRNAs of the samples were compared to the values of the control mRNA levels. After obtaining crude data, they were analyzed through the 7500 Software SDS program (Version 2.0.1). To calculate the level of expression of the selected genes, the following parameters were considered: $\mathrm{Ct}$ (exponential increase of the PCR product) of the target gene and endogenous control, $\Delta \mathrm{Ct}=\mathrm{Ct}$ (sample) - $\mathrm{Ct}$ (endogenous control), and $\Delta \Delta \mathrm{Ct}=\Delta \mathrm{Ct}$ (sample) $-\Delta \mathrm{Ct}$ (calibrator). After that, the level of expression was calculated by the formula: $R Q=2^{-\Delta \Delta C t}$. The program SigmaPlot was used for plotting the graphs.

\section{RESULTS AND DISCUSSION}

In the step corresponding to screening, experimental precision in evaluation of the inbred lines in regard to resistance to ear rot caused by $F$. verticillioides was high, as indicated by the value of the selective accuracy estimate obtained of 0.8463 . Accuracy is a parameter that refers to the correlation that exists between the true genotypic value of the genetic treatment and the values estimated or predicted from the data obtained in the experiment (Resende and Duarte, 2007). In addition, from the result of analysis of variance, it could be concluded that there is significant difference between the inbred lines in regard to the level of resistance to ear rot caused by F. verticillioides (data not shown). The climate conditions observed while carrying out the field experiment, with the drier climate during flowering and moisture during grain filling, were favorable to manifestation of symptoms caused by the pathogen and also contributed to screening of the inbred lines. According to White (1999), these conditions are ideal for high incidence of ear rot.

Mean heritability for the trait studied was $71.6 \%$, highlighting the existence of genetic variance and indicating high correspondence between the phenotype and genotype of the individuals. This result corroborated that obtained by Robertson et al. (2006), who obtained a heritability estimate of $80 \%$ for the trait of resistance to $F$. verticillioides. Likewise, resistance to ear rot caused by F. graminearum verified by Martin et al. (2012) also showed high heritability $\left(h^{2}=0.79\right)$.

Genetics and Molecular Research 16 (3): gmr16039415 
The mean percentages of damaged kernels obtained constituted only two groups according to the Scott-Knott test (Table 2). Variability among the inbred lines was more evident analyzing the mean percentages of damaged kernels, which ranged from 4.38 in inbred line 91 to 34.54 in inbred line 83, showing an amplitude of $30.16 \%$. In a study conducted for the purpose of investigating the response of maize hybrids inoculated with ear-rot-causing fungi in two different crop seasons, Mendes et al. (2012) obtained mean percentages of damaged kernels from 2.63 to $7.06 \%$ in the 2006/2007 crop year; the mean values did not differ among themselves statistically. However, in the 2007/2008 crop season, the values obtained ranged from 4.72 to $33.05 \%$, with statistical differences among the hybrids evaluated. According to the authors, the greater incidence of fungi in the second agricultural crop season was due to greater intensity of rain at the end of the crop cycle. The levels of resistance observed in this study compared to those observed by Mendes et al. (2012) in commercial hybrids in the second agricultural crop season can be considered high in dealing with a group of maize inbred lines, with low vigor. According to Hung and Holland (2012), hybrid vigor is important in expression of resistance to this disease because hybrids showed $27 \%$ fewer disease symptoms compared to the inbred lines. The four inbred lines that showed more promise in regard to resistance to ear rot were $22,37,58$, and 91 , and the most susceptible were $40,64,81$, and 83 (Table 2).

Table 2. Mean percentage of damaged kernels of 30 maize inbred lines. Lavras, MG, Brazil.

\begin{tabular}{l|c|c|c}
\hline Line & Mean percentage of damaged kernels & Line & Mean percentage of damaged kernels \\
\hline 83 & $34.54^{\mathrm{a}}$ & 3 & $17.10^{\mathrm{b}}$ \\
\hline 64 & $33.15^{\mathrm{a}}$ & 65 & $16.89^{\mathrm{b}}$ \\
\hline 81 & $27.64^{\mathrm{a}}$ & 9 & $15.79^{\mathrm{b}}$ \\
\hline 40 & $27.09^{\mathrm{a}}$ & 24 & $15.76^{\mathrm{b}}$ \\
\hline 12 & $26.87^{\mathrm{a}}$ & 43 & $15.44^{\mathrm{b}}$ \\
\hline 45 & $25.07^{\mathrm{a}}$ & 30 & $15.03^{\mathrm{b}}$ \\
\hline 25 & $24.99^{\mathrm{a}}$ & 26 & $15.02^{\mathrm{b}}$ \\
\hline $\mathrm{G} 3$ & $23.92^{\mathrm{a}}$ & 70 & $14.60^{\mathrm{b}}$ \\
\hline 84 & $23.09^{\mathrm{a}}$ & 93 & $13.69^{\mathrm{b}}$ \\
\hline 44 & $20.92^{\mathrm{a}}$ & $\mathrm{G} 2$ & $12.38^{\mathrm{b}}$ \\
\hline 57 & $20.68^{\mathrm{a}}$ & 59 & $11.31^{\mathrm{b}}$ \\
\hline 17 & $20.66^{\mathrm{a}}$ & 37 & $09.78^{\mathrm{b}}$ \\
\hline 63 & $20.28^{\mathrm{a}}$ & 22 & $06.84^{\mathrm{b}}$ \\
\hline 99 & $19.24^{\mathrm{b}}$ & 58 & $04.38^{\mathrm{b}}$ \\
\hline
\end{tabular}

Means followed by the same letter in the columns do not differ among themselves by the Scott-Knott test at the level of $1 \%$ probability.

In the summary of analyses of variance carried out per location, for all the characteristics evaluated in the inbred lines and hybrids, significant differences $(P \leq 0.01)$ could be observed for the genotype source of variation for all the characteristics in Lavras. It should be highlighted that success in evaluation of cultivars is directly dependent on experimental precision. In this case, precision was evaluated by selective accuracy $\left(\mathrm{r}_{\mathrm{gg}}\right)$. The results showed that there was high experimental precision since the $r_{\mathrm{gg}}$ values were mostly higher than 0.70 in the environment mentioned above for all the traits evaluated (Resende and Duarte, 2007). In addition, it was possible to detect significant differences among the genotypes for percentage of damaged kernels only in Lavras. Selective accuracy in this environment was of high magnitude (0.96429), indicating high experimental precision. Comparing this characteristic with the percentage of ears with symptoms of ear rot in Lavras, it can be inferred that evaluation 
of the percentage of damaged kernels was more efficient for evaluation of resistance, due to high selective accuracy compared to the accuracy of the second characteristic mentioned, which was 0.7030 .

In Inconfidentes, significant differences were observed only for percentage of ears with disease symptoms, there were not significant differences for percentage of damaged kernels. This may be attributed to selective accuracy for this characteristic, which was of low magnitude (0.2557), indicating low experimental precision. In this location, the climate conditions during the crop season were atypical, with a prolonged drought throughout the crop cycle, which hindered development of the disease and, consequently, the screening of genotypes in regard to resistance. This was evident upon comparing the mean percentage of damaged kernels among the locations. In Inconfidentes, this mean value was $1.29 \%$, whereas in Lavras the mean was $2.05 \%$, that is, $37 \%$ higher (Tables 3 and 4 ). For the characteristics of grain yield and percent of ears with symptoms of ear rot, the genotypes in Lavras obtained better results, around 11.95 and $4.9 \%$, respectively, in relation to those obtained in Inconfidentes (Tables 3 and 4).

Table 3. Mean values for the characteristics of percentage of damaged kernels (DK), percentage of ears with symptoms of ear rot (ER), and grain yield (YIELD) obtained in the experiments conducted in Lavras, MG, Brazil, 2015.

\begin{tabular}{|c|c|c|c|}
\hline Genotype & DK & ER & Yield \\
\hline 22 & $1.33^{\mathrm{c}}$ & 13.71 & $8,985.64$ \\
\hline 37 & $1.97^{\mathrm{c}}$ & 30.09 & $7,989.58$ \\
\hline 40 & $15.50^{\mathrm{a}}$ & 38.54 & $1,239.81$ \\
\hline 58 & $2.51^{\mathrm{c}}$ & 8.76 & $6,987.50$ \\
\hline 64 & $5.44^{\mathrm{c}}$ & 30.99 & 562.73 \\
\hline 81 & $8.74^{\mathrm{b}}$ & 57.46 & $1,483.56$ \\
\hline 83 & $6.76^{\mathrm{b}}$ & 29.49 & 659.02 \\
\hline 91 & $0.50^{\mathrm{c}}$ & 18.42 & $9,647.68$ \\
\hline $22 / 40$ & $1.31^{\mathrm{c}}$ & 13.88 & $8,756.94$ \\
\hline $22 / 64$ & $1.46^{\mathrm{c}}$ & 41.20 & $9,385.87$ \\
\hline $22 / 81$ & $1.09^{\mathrm{c}}$ & 8.36 & $9,491.20$ \\
\hline $22 / 83$ & $2.06^{\mathrm{c}}$ & 30.46 & $8,031.71$ \\
\hline $37 / 40$ & $1.15^{\mathrm{c}}$ & 34.97 & $7,174.07$ \\
\hline $37 / 64$ & $1.26^{\mathrm{c}}$ & 14.67 & $7,809.62$ \\
\hline $37 / 81$ & $1.53^{\mathrm{c}}$ & 14.82 & $9,250.46$ \\
\hline $37 / 83$ & $1.07^{\mathrm{c}}$ & 26.32 & $6,193.05$ \\
\hline $40 / 22$ & $2.15^{\mathrm{c}}$ & 27.21 & $9,397.91$ \\
\hline $40 / 37$ & $1.83^{\mathrm{c}}$ & 25.42 & $7,851.15$ \\
\hline $40 / 58$ & $2.25^{\mathrm{c}}$ & 7.69 & $8,621.52$ \\
\hline $40 / 91$ & $1.01^{\mathrm{c}}$ & 8.59 & $8,940.50$ \\
\hline $58 / 40$ & $1.37^{\mathrm{c}}$ & 17.64 & $9,003.70$ \\
\hline 58/64 & $0.54^{\mathrm{c}}$ & 11.59 & $8,137.03$ \\
\hline $58 / 81$ & $0.50^{\mathrm{c}}$ & 9.29 & $6,235.18$ \\
\hline $\begin{array}{l}58 / 83 \\
\end{array}$ & $0.62^{\mathrm{c}}$ & 5.98 & $7,083.79$ \\
\hline $64 / 22$ & $1.52^{\mathrm{c}}$ & 12.30 & $8,474.07$ \\
\hline $64 / 37$ & $1.11^{\mathrm{c}}$ & 21.68 & $7,429.86$ \\
\hline $64 / 58$ & $1.73^{\mathrm{c}}$ & 41.89 & $8,137.03$ \\
\hline $64 / 91$ & $0.57^{\mathrm{c}}$ & 13.76 & $10,153.24$ \\
\hline $81 / 22$ & $1.39^{\mathrm{c}}$ & 13.25 & $9,671.75$ \\
\hline $81 / 37$ & $0.46^{\mathrm{c}}$ & 17.55 & $7,411.80$ \\
\hline $81 / 58$ & $1.45^{\mathrm{c}}$ & 10.53 & $9,124.07$ \\
\hline $81 / 91$ & $0.87^{\mathrm{c}}$ & 14.98 & $7,493.05$ \\
\hline $83 / 22$ & $1.08^{\mathrm{c}}$ & 39.48 & $7,273.37$ \\
\hline $83 / 37$ & $0.81^{\mathrm{c}}$ & 25.54 & $5,591.20$ \\
\hline $83 / 58$ & $1.17^{\mathrm{c}}$ & 47.38 & $7,291.43$ \\
\hline $83 / 91$ & $1.94^{\mathrm{c}}$ & 39.48 & $8,218.28$ \\
\hline $91 / 40$ & $0.51^{\mathrm{c}}$ & 7.13 & $8,991.66$ \\
\hline $91 / 64$ & $0.67^{\mathrm{c}}$ & 1.59 & $9,151.15$ \\
\hline $91 / 81$ & $0.85^{\mathrm{c}}$ & 10.42 & $8,844.21$ \\
\hline $91 / 83$ & $1.26^{\mathrm{c}}$ & 16.37 & $6,581.25$ \\
\hline
\end{tabular}

Means followed by the same letter in the columns do not differ among themselves by the Scott-Knott test at the level of $1 \%$ probability.

Genetics and Molecular Research 16 (3): gmr16039415 
Table 4. Mean values for the characteristics of percentage of damaged kernels (DK), percentage of ears with symptoms of ear rot (ER), and grain yield (YIELD) obtained in the experiments conducted in Inconfidentes, MG, Brazil, 2015.

\begin{tabular}{|c|c|c|c|}
\hline Genotype & DK & ER & Yield \\
\hline 22 & $1.36^{\mathrm{a}}$ & 4.34 & $7,898.15$ \\
\hline 37 & $4.28^{\mathrm{a}}$ & 19.24 & $7,555.52$ \\
\hline 40 & $4.23^{\mathrm{a}}$ & 34.33 & $3,634.71$ \\
\hline 58 & $5.91^{\mathrm{a}}$ & 4.36 & $6,428.69$ \\
\hline 64 & $1.25^{\mathrm{a}}$ & 44.49 & $1,939.18$ \\
\hline 81 & $0.79^{\mathrm{a}}$ & 17.69 & $4,381.48$ \\
\hline 83 & $0.70^{\mathrm{a}}$ & 94.29 & $1,717.55$ \\
\hline 91 & $0.57^{\mathrm{a}}$ & 8.87 & $9,122.92$ \\
\hline $22 / 40$ & $0.68^{\mathrm{a}}$ & 12.76 & $8,272.23$ \\
\hline $22 / 64$ & $0.78^{\mathrm{a}}$ & 37.18 & $6,041.73$ \\
\hline $22 / 81$ & $2.08^{\mathrm{a}}$ & 13.54 & $7,487.99$ \\
\hline $22 / 83$ & $1.93^{\mathrm{a}}$ & 39.37 & $5,049.96$ \\
\hline $37 / 40$ & $2.13^{\mathrm{a}}$ & 21.04 & $7,530.14$ \\
\hline $37 / 64$ & $0.77^{\mathrm{a}}$ & 5.12 & $5,866.72$ \\
\hline $37 / 81$ & $1.85^{\mathrm{a}}$ & 7.99 & $7,566.84$ \\
\hline $37 / 83$ & $0.75^{\mathrm{a}}$ & 12.74 & $8,926.20$ \\
\hline $40 / 22$ & $1.20^{\mathrm{a}}$ & 22.75 & $8,821.38$ \\
\hline $40 / 37$ & $0.72^{\mathrm{a}}$ & 7.43 & $9,300.00$ \\
\hline $40 / 58$ & $1.06^{\mathrm{a}}$ & 17.31 & $8,575.64$ \\
\hline $40 / 91$ & $1.36^{\mathrm{a}}$ & 11.40 & $9,174.00$ \\
\hline $58 / 40$ & $1.64^{\mathrm{a}}$ & 34.79 & $6,392.28$ \\
\hline $58 / 64$ & $1.77^{\mathrm{a}}$ & 35.31 & $6,119.29$ \\
\hline $58 / 81$ & $1.55^{\mathrm{a}}$ & 2.89 & $5,835.45$ \\
\hline $58 / 83$ & $1.60^{\mathrm{a}}$ & 17.82 & $3,843.98$ \\
\hline $64 / 22$ & $1.25^{\mathrm{a}}$ & 12.62 & $7,633.10$ \\
\hline $64 / 37$ & $1.02^{\mathrm{a}}$ & 26.55 & $8,164.72$ \\
\hline $64 / 58$ & $1.08^{\mathrm{a}}$ & 38.00 & $7,185.32$ \\
\hline $64 / 91$ & $1.06^{\mathrm{a}}$ & 4.53 & $6,048.93$ \\
\hline $81 / 22$ & $1.49^{\mathrm{a}}$ & 21.38 & $5,345.82$ \\
\hline $81 / 37$ & $1.20^{\mathrm{a}}$ & 13.26 & $6,586.71$ \\
\hline $81 / 58$ & $1.05^{\mathrm{a}}$ & 13.10 & $5,336.80$ \\
\hline $81 / 91$ & $0.70^{\mathrm{a}}$ & 6.41 & $5,881.84$ \\
\hline $83 / 22$ & $1.24^{\mathrm{a}}$ & 51.90 & $6,634.21$ \\
\hline $83 / 37$ & $1.24^{\mathrm{a}}$ & 12.22 & $7,518.13$ \\
\hline $83 / 58$ & $0.90^{\mathrm{a}}$ & 34.05 & $6,936.18$ \\
\hline $83 / 91$ & $0.11^{\mathrm{a}}$ & 33.59 & $5,557.30$ \\
\hline $91 / 40$ & $0.34^{\mathrm{a}}$ & 3.00 & $9,002.67$ \\
\hline $91 / 64$ & $1.29^{\mathrm{a}}$ & 2.15 & $9,189.25$ \\
\hline $91 / 81$ & $0.17^{\mathrm{a}}$ & 19.11 & $4,938.49$ \\
\hline $91 / 83$ & $0.10^{\mathrm{a}}$ & 19.78 & $5,624.59$ \\
\hline
\end{tabular}

Means followed by the same letter in the columns do not differ among themselves by the Scott-Knott test at the level of $1 \%$ probability.

The estimate of heritability of the percentage of ear rot obtained from the data collected in Lavras was 0.93 , indicating that genetic value is very well represented by phenotypic value in this location. As already mentioned, this result emphasizes the existence of genetic variation for the characteristic and the possibility of success in the selection process. From the magnitudes of heritability obtained, it can be seen that the method of evaluation of the proportion of damaged kernels proved to be the more appropriate methodology for discrimination of resistance of genotypes to ear rot caused by $F$. verticillioides in Lavras compared to the methodology of evaluation of the percentage of ears with disease symptoms, which exhibited a lower estimate of heritability (49.43\%), associated with lower environmental precision. Nevertheless, the results obtained in Inconfidentes were contrary to those obtained in the other location since the trait exhibited greater heritability $(76.18 \%)$.

Through the result of combined analysis of variance (data not shown), it was observed that the genotypes responded in a different way in relation to percentage of damaged kernels 
and to yield in the environments where the experiments were carried out, indicating influence of the environment on the response of the hybrids and inbred lines evaluated. Nevertheless, when the genotypes were evaluated in the two environments in a combined manner, they did not differ statistically for this characteristic. In this study, all the characteristics exhibited low heritability in combined analysis. Nevertheless, the percentage of ears with disease symptoms showed higher magnitude for heritability (11.68\%) in relation to the estimate of heritability of the other characteristic related to resistance when the two locations were considered. Experimental precision for this trait was high, according to the accuracy estimate of 0.84 (Resende and Duarte, 2007).

In the literature, there are many reports that the effect of the genotype $\mathrm{x}$ environment interaction has a big influence on the trait of resistance to ear rot (Olatinwo et al., 1999; Mukanga et al., 2010). This occurs because the development of pathogens of the ear-rot complex is highly influenced by environmental conditions. The genotype $\mathrm{x}$ environment interaction hinders selection of superior genotypes with the desired level of resistance to this disease throughout the period of the breeding program because development of the disease is highly influenced by environmental conditions and may lead to incorrect estimates of resistance and, consequently, to lack of success in selection. Thus, divergence between the locations may have contributed to differentiate development of the pathogen in experimental areas, which generated an inconsistent response of the genotypes in these environments (Matheson and Raymond, 1986).

Diallel analysis carried out with the data obtained in Lavras showed that the effect of SCA was highly significant and there were no differences between the GCA of the inbred lines and the reciprocals either for the characteristic of percentage of damaged kernels or for percentage of ears with disease symptoms (Table 5). However, the results obtained in Inconfidentes showed that the effects of GCA and reciprocals were not significant for the percentage of damaged kernels, as it was expected considering that the effect of the genotypes for this characteristic was not significant in this location. Nevertheless, the results for the other characteristic corroborate those obtained in Lavras.

The results of diallel analysis per location indicated that the non-additive effects were more relevant for explaining control of resistance. Thus, it is evident that this characteristic may be introduced through hybrid vigor. A significant effect of reciprocals for the two characteristics connected with disease resistance was not observed in either of the locations, indicating predominance of the action of nuclear genes and absence of maternal effect or of extrachromosomal inheritance.

Considering combined diallel analysis for the characteristic of percentage of damaged kernels, it can be observed that the mean square of the GCA was not significant (Table 6), just as in the analyses per location shown. This reinforces that the genotypes do not differ among themselves in the GCA.

The SCA, for its part, was also significant in combined analysis, which indicates that there are hybrids formed from crossing inbred lines that show better performance than others, due to the non-additive effects involved in genetic control, which may indicate the presence of heterosis for the trait in question. This result corroborated that obtained by Hung and Holland (2012), who observed $27 \%$ fewer disease symptoms in the hybrids, showing the importance of hybrid vigor in resistance to ear rot.

As the effect of the SCA $x$ environment interaction was significant $(\mathrm{P} \leq 0.05)$, it is assumed that the crosses are heterogeneous and differ from the response expected as based on

Genetics and Molecular Research 16 (3): gmr16039415 
Table 5. Summary of the diallel analyses for the characteristics of percentage of damaged kernels (DK) and the percentage of ears with symptoms of ear rot (ER), obtained in the experiments conducted in Lavras and Inconfidentes, MG, Brazil, 2014.

\begin{tabular}{|c|c|c|c|}
\hline & \multicolumn{3}{|c|}{ Lavras } \\
\hline & & Mean square & \\
\hline SV & DF & DK & ER \\
\hline Genotypes (G) & 63 & $16.9105^{* *}$ & $654.97 * *$ \\
\hline G.C.A. & 7 & $21.0134^{\mathrm{n} . \mathrm{s}}$ & $341.97^{\mathrm{n} . \mathrm{s}}$ \\
\hline S.C.A. & 28 & $32.3894 * *$ & $1136.16^{* *}$ \\
\hline Reciprocal & 28 & $0.4582^{\mathrm{n} . \mathrm{s}}$ & $252.01^{\text {n.s }}$ \\
\hline \multirow[t]{3}{*}{ Residue } & 78 & 1.5632 & 322.12 \\
\hline & \multicolumn{3}{|c|}{ Inconfidentes } \\
\hline & & Mean square & \\
\hline SV & DF & DK & ER \\
\hline Genotypes (G) & 63 & $3.731319^{\mathrm{n} . \mathrm{s}}$ & $890.06^{* *}$ \\
\hline G.C.A. & 7 & $5.325418^{\text {n.s }}$ & $1623.87^{\text {n.s }}$ \\
\hline S.C.A. & 28 & $32.3894 * *$ & $1136.16^{* *}$ \\
\hline Reciprocal & 28 & $0.4582^{\mathrm{n} . \mathrm{s}}$ & $252.01^{\mathrm{n} . \mathrm{s}}$ \\
\hline Residue & 78 & 1.5632 & 322.12 \\
\hline
\end{tabular}

*,**Significant at 5 and $1 \%$ of probability by the $\mathrm{F}$ test; ${ }^{\mathrm{n} . \mathrm{s}}$ not significant; $\mathrm{r}_{\mathrm{gg}}$ - selective accuracy.

Table 6. Breakdown of the effect of genotypes on general combining ability (GCA), specific combining ability (SCA), and GCA x location and SCA x location interactions for the percentage of damaged kernels caused by $F$. verticillioides, considering combined diallel analysis involving the two locations. UFLA, Lavras, MG, Brazil, 2015.

\begin{tabular}{l|c|c|c}
\hline SV & DF & MS & Fc \\
\hline Genotypes (G) & 63 & 14.241628 & $2.23^{\text {n.s }}$ \\
\hline G.C.A. & 7 & 15.039359 & $1.33^{\text {n.s }}$ \\
\hline S.C.A. & 28 & 27.979843 & $2.51^{*}$ \\
\hline Reciprocal (R) & 28 & 0.33398 & $0.75^{\text {n.s }}$ \\
\hline Environment (E) & 1 & 16.1376 & $1.91^{*}$ \\
\hline Gx E & 63 & 6.40001 & $3.36^{*}$ \\
\hline G.C.A. x E & 7 & 11.2994 & $3.31^{*}$ \\
\hline S.C.A. $x$ E & 28 & 11.1304 & $0.13^{\text {n.s }}$ \\
\hline Rx E & 28 & 0.445098 & 3.358 \\
\hline Residue & 156 & 3 & \\
\hline
\end{tabular}

**** Significant at 1 and $5 \%$ probability, respectively, by the $\mathrm{F}$ test; ${ }^{\mathrm{n} . \mathrm{s}}$ non-significant, by the $\mathrm{F}$ test.

the general combining ability of their parent inbred lines, and also that the heterosis obtained by the hybrids varied in the two locations. Highly significant effects of SCA and GCA among the environments evaluated and in each one individually were found by Mukanga et al. (2010). Moreover, the authors observed that the SCA was that which most contributed to resistance, indicating the predominance of dominance effects for resistance to the three fungi that cause ear rot, among which is $F$. verticillioides.

A significant effect of the reciprocal effect was not found for percentage of damaged kernels, as in analyses per location. Dorrace and Hinkelmann (1998) also did not find an effect of the reciprocals in crosses of maize inbred lines aiming at resistance to Stenocarpella maydis, indicating that resistance can be controlled by nuclear genes and there is no maternal effect. In contrast, Mukanga et al. (2010) observed differences among the reciprocal crosses, indicating interaction between nuclear genes and those of the cytoplasm and occurrence of the maternal effect in control of multiple resistance to Aspergillus flavus, F. verticillioides, and Stenocarpella maydis in maize. Kovács et al. (1994) aimed to check the occurrence of maternal effect for resistance to ear rot in reciprocal crosses and observed correlations between the hybrids and female parent and between hybrids and male parent of 0.65 and 0.85 , respectively. These results showed a strong paternal influence.

Genetics and Molecular Research 16 (3): gmr16039415 
Considering combined diallel analysis of evaluation of the percentage of ears with symptoms of ear rot caused by $F$. verticillioides, a significant effect was not observed among the interactions (Table 7). The SCA effect was significant, in agreement with the diallel analyses per location; however, differences were found among the reciprocals in combined analysis.

Table 7. Breakdown of the genotype effect in general combining ability (GCA), specific combining ability (SCA), and GCA x location and SCA x location interactions for percentage of ears with symptoms of ear rot caused by $F$. verticillioides, considering combined diallel analysis involving the two locations. UFLA, Lavras, MG, Brazil, 2015.

\begin{tabular}{l|c|c|c}
\hline SV & DF & MS & Fc \\
\hline Genotypes (G) & 63 & 1322.42 & $5.9^{*}$ \\
\hline G.C.A. & 7 & 1517.82 & $3.38^{\text {n.s }}$ \\
\hline S.C.A. & 28 & 2261.95 & $6.93^{*}$ \\
\hline Reciprocal (R) & 28 & 334.03 & $5.32^{*}$ \\
\hline Environment (E) & 1 & 9.54 & $0.79^{\text {n.s }}$ \\
\hline Gx E & 63 & 222.61 & $1.59^{\text {n.s }}$ \\
\hline G.C.A. x E & 7 & 448.03 & $1.16^{\text {n.s }}$ \\
\hline S.C.A. $x$ E & 28 & 326.09 & $0.27^{\text {n.s }}$ \\
\hline R x E & 28 & 62.77 & \\
\hline Residue & 156 & 280.09 & \\
\hline
\end{tabular}

**,*Significant at 1 and 5\% probability, respectively, by the $\mathrm{F}$ test; ${ }^{\mathrm{n} . \mathrm{s}}$ non-significant, by the $\mathrm{F}$ test.

Although the effect of general combining ability was not significant for the characteristics related to ear rot, it is noteworthy that in Lavras all the inbred lines classified as resistant showed negative values of the effect of general combining ability, corroborating the result obtained in screening of the inbred lines for percentage of ear rot caused by $F$. verticillioides in the 2011/2012 crop season.

When the $\mathrm{g}_{\mathrm{i}}$ values are high, either positive or negative, it is a sign that the parent in question is superior or inferior to the other parents of the diallel in relation to mean performance of the progenies (Cruz and Regazzi, 2001). Nevertheless, for the characteristic of percentage of damaged kernels, it is desirable that the inbred line has negative $g_{i}$ in the sense of reducing the percentage of these infected kernels.

In relation to estimates of $g_{i}$, inbred line 91 obtained the greatest negative and significant value for the characteristic of percentage of damaged kernels in the two locations, which indicates a tendency of reduction in the percentage of damaged kernels in the crosses in which this genotype participates. Inbred line 22 also exhibited a negative value in the two environments for percentage of damaged kernels, whereas inbred line 58 exhibited a negative value for percentage of ears with disease symptoms in the two environments.

Thus, inbred lines 22, 58, and 91 showed greater concentration of favorable alleles for an increase in resistance and have potential to be introduced in breeding programs and used as parent inbred lines in hybrid crosses when genotypes more responsive to resistance to $F$. verticillioides are desired.

Inbred line 64, classified in screening as susceptible to ear rot also exhibited negative and significant $\mathrm{g}_{\mathrm{i}}$ in the two environments for percentage of damaged kernels, whereas inbred line 81 showed negative $g_{i}$ in the two environments for the other characteristic related to resistance (Table 8).

The values of the effects of specific combining ability (sij) indicate that some specific combinations are better or worse than expected, based on the GCA of the parents. The greatest negative values for the percentage of damaged kernels were observed in the crosses between inbred lines $40 \times 91$ in Lavras and between inbred lines 40 x 37 in Inconfidentes, showing

Genetics and Molecular Research 16 (3): gmr16039415 
the presence of heterosis due to complementarity between the genotypes and confirming the significant result for the SCA effect (Table 9). The values of sij are an important indication of the genes that exhibit epistasis and dominance effects and are measures of non-additive gene effects (Sprague and Tatum, 1942). In these hybrids, inbred lines 91 and 37 are involved, which exhibit a negative effect of $g_{i}$ for percentage of damaged kernels (Table 8).

Table 8. Estimates of the effects of general combining ability $(g i)$ for percentage of damaged kernels and for percentage of ears with symptoms of ear rot from 40 genotypes, evaluated in two locations, in a partial diallel cross arrangement. UFLA, Lavras, MG, Brazil, 2015.

\begin{tabular}{|c|c|c|}
\hline \multicolumn{3}{|l|}{ Lavras } \\
\hline Line & $\mathrm{g}_{\mathrm{i}} \mathrm{DK}$ & $\mathrm{g}_{\mathrm{i}} \mathrm{ER}$ \\
\hline 40 & 1.39 & 0.306 \\
\hline 64 & -0.037 & 0.371 \\
\hline 81 & 0.33 & -0.037 \\
\hline 83 & 0.2 & 4.704 \\
\hline 22 & -0.351 & -0.072 \\
\hline 37 & -0.448 & 1.652 \\
\hline 58 & -0.355 & -2.826 \\
\hline 91 & -0.728 & -4.098 \\
\hline \multicolumn{3}{|c|}{ Inconfidentes } \\
\hline Line & $\mathrm{g}_{\mathrm{i}} \mathrm{DK}$ & $\mathrm{g}_{\mathrm{i}} \mathrm{ER}$ \\
\hline 40 & 0.238 & -0.658 \\
\hline 64 & -0.141 & 2.54 \\
\hline 81 & -0.132 & -4.788 \\
\hline 83 & -0.288 & 12.523 \\
\hline 22 & -0.025 & 0.657 \\
\hline 37 & 0.279 & -4.053 \\
\hline 58 & 0.543 & -0.658 \\
\hline 91 & -0.475 & 2.54 \\
\hline
\end{tabular}

Table 9. Estimates of the effects of specific combining ability (sij) of 40 genotypes for the characteristic of percentage of damaged kernels caused by Fusarium verticillioides, evaluated in two locations, in a partial diallel cross arrangement involving eight inbred lines. UFLA, Lavras, MG, Brazil, 2015.

\begin{tabular}{l|c|c}
\hline \multirow{2}{*}{ Cross } & Lavras & Inconfidentes \\
\cline { 2 - 3 } & $S_{i j}$ & -0.134 \\
\hline $40 \times 22$ & -0.580 & -0.470 \\
\hline $40 \times 37$ & -0.723 & -0.293 \\
\hline $40 \times 58$ & -0.496 & 0.226 \\
\hline $40 \times 91$ & -1.173 & 0.320 \\
\hline $64 \times 22$ & 0.607 & -0.104 \\
\hline $64 \times 37$ & 0.400 & 0.162 \\
\hline $64 \times 58$ & 0.257 & 0.930 \\
\hline $64 \times 91$ & 0.115 & 1.081 \\
\hline $81 \times 22$ & -0.010 & 0.517 \\
\hline $81 \times 37$ & -0.158 & 0.027 \\
\hline $81 \times 58$ & -0.271 & 0.181 \\
\hline $81 \times 91$ & -0.013 & 1.037 \\
\hline $83 \times 22$ & 0.450 & 0.143 \\
\hline $83 \times 37$ & -0.082 & 0.134 \\
\hline $83 \times 58$ & -0.220 & -0.43 \\
\hline $83 \times 91$ & 0.858 & \\
\hline
\end{tabular}

The best performance of the hybrids in Lavras for percentage of diseased ears were those formed between inbred lines 64 x 91, 40 x 91, and 81 x 22, and in Inconfidentes, hybrids $64 \times 91$ and $83 \times 37$ stood out (Table 10). These results confirm the potential of inbred lines 91 as a donor of alleles favorable to resistance to damaged kernels caused by F. verticillioides. 
The single hybrid $40 \times 91$ was the most promising in relation to resistance to damaged kernels in Lavras since this genotype exhibited high values of sij for the two characteristics related to this trait.

Table 10. Estimates of the effects of specific combining ability (sij) of 40 genotypes for the characteristic of percentage of ears with symptoms of ear rot caused by Fusarium verticillioides, evaluated in two locations, in a partial diallel cross arrangement involving eight inbred lines. UFLA, Lavras, MG, Brazil, 20015.

\begin{tabular}{l|c|c}
\hline \multirow{2}{*}{ Cross } & Lavras & Inconfidentes \\
\cline { 2 - 3 } & $S_{i j}$ & \multicolumn{2}{c}{$s_{i j}$} \\
\hline $40 \times 22$ & 6.892 & 5.842 \\
\hline $40 \times 37$ & 14.818 & 14.084 \\
\hline $40 \times 58$ & -1.765 & 0.502 \\
\hline $40 \times 91$ & -1.768 & 8.591 \\
\hline $64 \times 22$ & 13.031 & 4.235 \\
\hline $64 \times 37$ & 2.732 & -6.483 \\
\hline $64 \times 58$ & 15.774 & -6.565 \\
\hline $64 \times 91$ & -2.019 & 6.487 \\
\hline $81 \times 22$ & -2.505 & 6.362 \\
\hline $81 \times 37$ & 1.151 & 0.159 \\
\hline $81 \times 58$ & -0.647 & 10.192 \\
\hline $81 \times 91$ & 3.415 & 19.35 \\
\hline $83 \times 22$ & 16.918 & -9.095 \\
\hline $83 \times 37$ & 6.156 & 0.787 \\
\hline $83 \times 58$ & 11.381 & 6.805 \\
\hline $83 \times 91$ & 13.898 & \\
\hline
\end{tabular}

It is clear that the breeder should focus attention on obtaining increasingly higher yielding hybrids and should select inbred lines with low percentage of damaged kernels and considerable heterosis for other traits. Therefore, this study of genetic inheritance of resistance to $F$. verticillioides is highly important for directing maize breeding programs in Brazil.

The results of analysis of gene expression generally indicated great variation of expression of the genes analyzed in the tissues collected from the different inbred lines 48 hours after their inoculation with $F$. verticillioides. The reliability of the results of RT-qPCR is due to the use of a reference gene, or endogenous gene, which exhibits the same level of expression regardless of the treatment the sample underwent; in this study, the endogenous genes used were ubiquitin and $\mathrm{ADH}$.

Among all the primers tested, only five - Hsp90, LOX8, GPN1, Hsp82, and LOX 11 - exhibited satisfactory amplification to be analyzed in all the plots.

In Figure 3, the relative expression of the Hsp90 gene in relation to the tissues of the eight inbred lines is represented. The gene expressed in a similar manner in most inbred lines, with greater expression in inbred lines 64 and 91 and lower expression in inbred line 83 .

Expression of the Hsp90 gene apparently did not relate to classification of the inbred lines in relation to susceptibility and resistance to the symptoms caused by $F$. verticillioides in the kernels. However, inbred lines 83, which had a greater percentage of damaged kernels, had the lowest expression of this gene. Considering that the Hsp90 gene codifies for heat shock protein with a weight of $90 \mathrm{kDa}$, and that these proteins are related to protection of cells against various kinds of stresses, low expression was expected not only in inbred line 83 but also in all the other susceptible inbred lines. It is important to emphasize that inbred line 64, susceptible to the disease under study, exhibited greatest expression of this gene.

Genetics and Molecular Research 16 (3): gmr16039415 


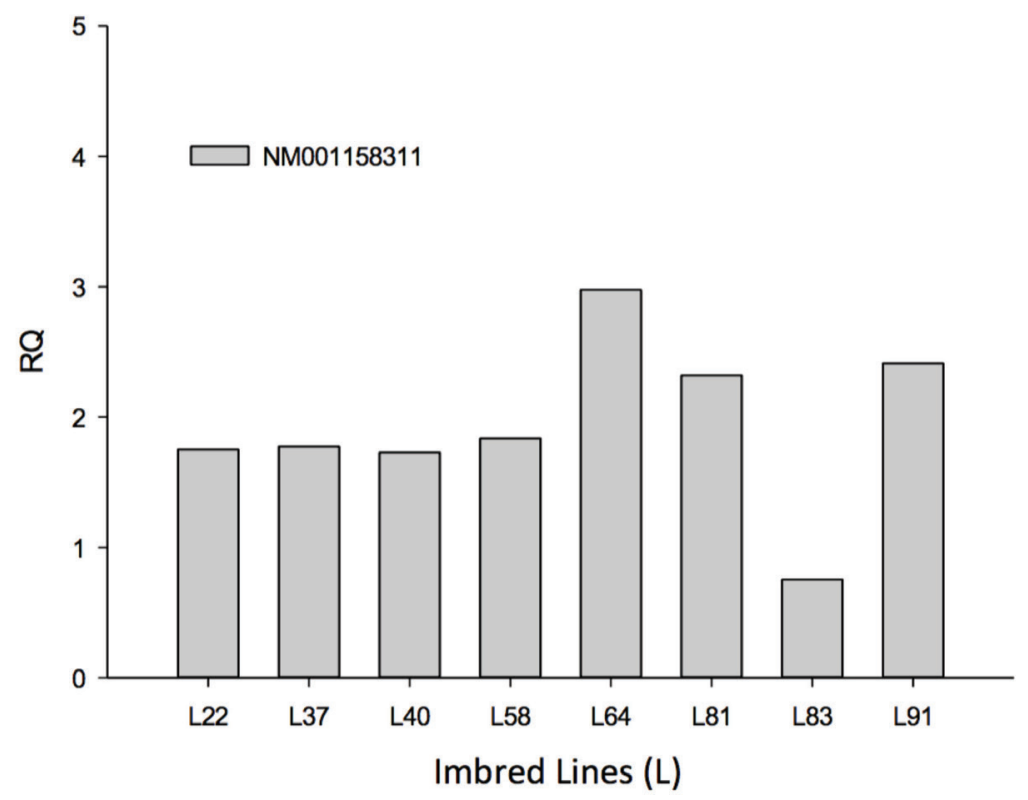

Figure 3. Profile of relative quantitative expression of the Hsp90 gene in seeds of maize inbred lines resistant (22, $58,37,91)$ and susceptible $(40,64,81,83)$ to ear rot caused by Fusarium verticillioides.

Relative quantitative expression of the gene LOX8, which codifies for a type of lipoxygenase represented in Figure 4, once more shows the differentiation of inbred line 83, the most vulnerable to ear rot in relation to the others; however, in this case, greater expression of the gene was observed. The lipoxygenases catalyze reactions of incorporation of oxygen in free fatty acids in the carbon chain that have lipid oxides as a product, such as jasmonic acid and methyl jasmonate, involved in inter- and intracellular communication and, above all, in the defense mechanism of the plants.

In addition, it was observed that the lipid oxides produced by the pathway of the 9-LOX, codified by the gene $\mathrm{ZmLOX3}$, in maize were required by three different fungal pathological agents of the maize crop, among them $F$. verticillioides, to produce spores and mycotoxins and, consequently, to colonize the hosts (Gao et al., 2008). The lipoxygenases codified by the genes ZmLOX6 and ZmLOX11 were significantly more abundant in the susceptible inbred line B73 in relation to the inbred line tolerant to F. gramineareum $\mathrm{C} 0441$ in a proteomic study carried out by Mohammadi et al. (2011). Thus, relative expression of the gene $\mathrm{ZmLOX8}$ was expected to be high in the tissues of the four susceptible inbred lines; however, only inbred line 83 had the expected result.

The results in Figure 5 show high relative expression of the gene GPN1 in inbred line 81 in relation to the others, which is also highly susceptible to disease. Gene GPN1 codifies for the enzyme glyceraldehyde-3-phosphate dehydrogenase responsible for addition of a hydrogen molecule to the NAD, forming NADH in a glycolysis step. Possibly, the increase in the activity of this enzyme is understandable due to the increase in respiration of plants affected by attack from pathogens because the diseased tissues come to use their carbohydrate reserves as a function of the increase in metabolic activity; that is, biosynthesis and accumulation of 
various compounds linked to defense mechanisms. Nevertheless, expression of the GPN1 gene was apparently not related to inbred line 83 . On the contrary, greater expression of this gene was observed in resistant inbred lines 22 and 91 compared to inbred line 83.

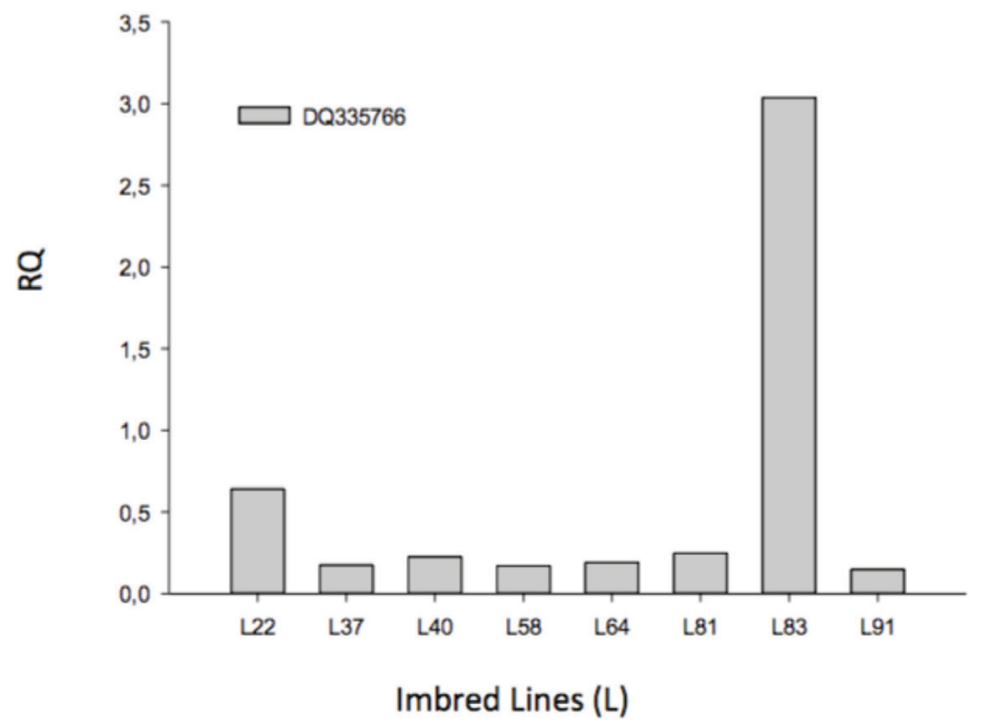

Figure 4. Profile of relative quantitative expression of the gene LOX 8 in seeds of maize inbred lines resistant (22, $58,37,91)$ and susceptible $(40,64,81,83)$ to ear rot caused by Fusarium verticillioides.

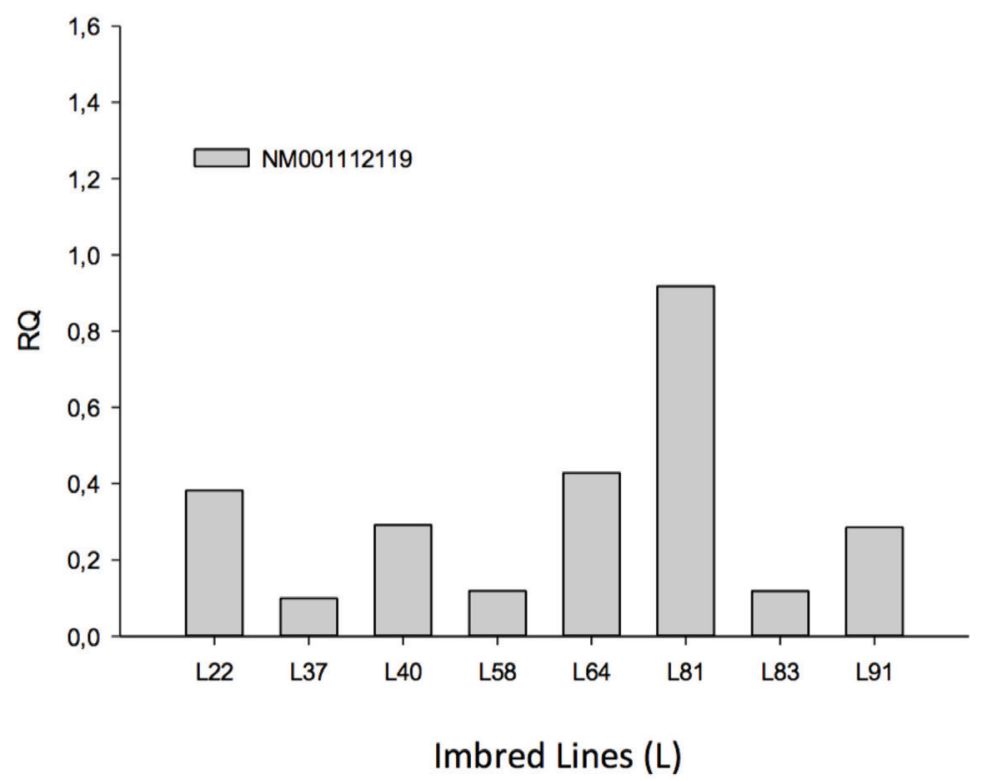

Figure 5. Profile of relative quantitative expression of the gene GPN1 in seeds of maize inbred lines resistant (22, $58,37,91)$ and susceptible $(40,64,81,83)$ to ear rot caused by Fusarium verticillioides.

Genetics and Molecular Research 16 (3): gmr16039415 
Quantitative expression of the gene Hsp82, observed in Figure 6, was also lower in inbred line 83, which corroborated the result observed when expression of the gene Hsp90. The Hsp are a group of highly conserved proteins in plants and have the function of reestablishing cell homeostasis and the stability of cell membranes under stress conditions (Wang et al., 2004). In tomato, rapid accumulation of proteins related to the plant defense mechanism was observed, among which are some varieties of Hsp, after inoculation with Sclerotinia sclerotiorum; nevertheless, the resistant inbred lines and tolerant inbred lines responded in a similar manner to infection with the fungus (Gorovits et al., 2007).

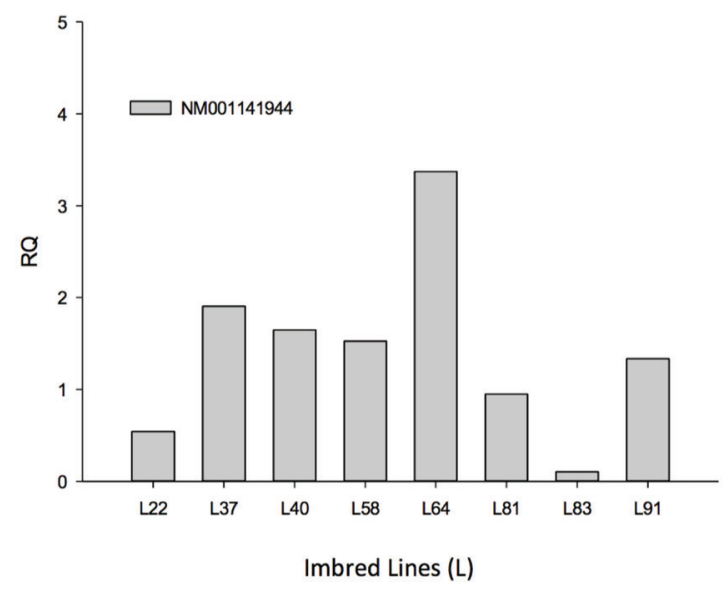

Figure 6. Profile of relative quantitative expression of the gene Hsp82 in seeds of maize inbred lines resistant (22, $58,37,91)$ and susceptible $(40,64,81,83)$ to ear rot caused by Fusarium verticillioides.

In Figure 7, relative expression of the gene LOX11 is represented in relation to the tissues of the eight inbred lines. It was observed that the expression pattern of this gene was not consistent to differentiate the inbred lines in relation to susceptibility and resistance to symptoms caused by $F$. verticillioides in maize.

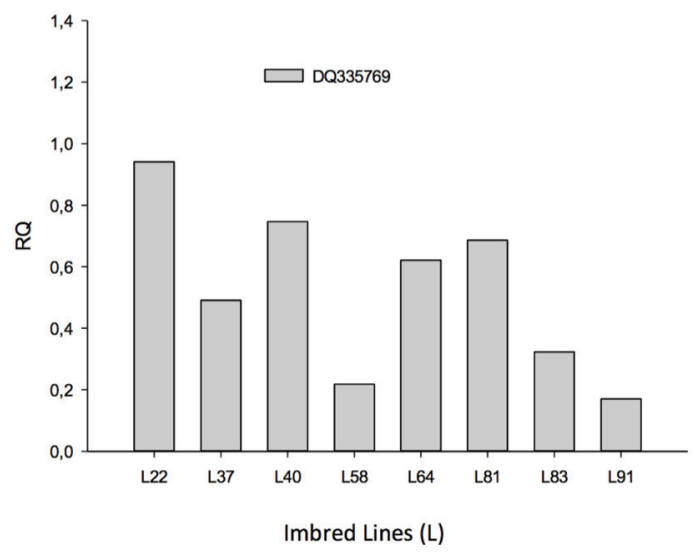

Figure 7. Profile of relative quantitative expression of the gene LOX11 in seeds of maize inbred lines resistant (22, $58,37,91)$ and susceptible $(40,64,81,83)$ to ear rot caused by Fusarium verticillioides. 
From the results obtained, only the genes LOX8 and Hsp82 showed a satisfactory result in order to be related to the plant defense mechanism when there is ear rot, although expression of these genes was observed in only one susceptible genotype. It was expected that the genes analyzed would be expressed differently in the inbred lines of the same classification since resistance to ear rot caused by F. verticillioides and other fungi of the ear rot complex is a characteristic of polygenic inheritance with complex genetic control (Mesterházy et al., 2012).

From these considerations, it can be suggested that studies focusing on molecular analyses may lead to great benefits in understanding the mechanisms involved in resistance to biotic stresses and contribute to selection or development of superior genotypes.

With this study, it is concluded that there is genetic variability among maize inbred lines for resistance to ear rot caused by F. verticillioides. Inbred lines 22, 58, and 91 have potential for use in breeding programs aiming at resistance to $F$. verticillioides. The characteristic studied related to resistance to ear rot is controlled by genes whose effects are predominantly non-additive. There is no reciprocal effect for the characteristic studied related to resistance to ear rot caused by F. verticillioides. Most of the highest yielding genotypes evaluated in this study are also those that showed the lowest percentage of ear rot. In this study, relative expressions of the genes evaluated are not consistent with classification of the inbred lines. The genes LOX8 and Hsp82 are potential molecular markers for selection of maize inbred lines resistant to $F$. verticillioides.

\section{ACKNOWLEDGMENTS}

Research supported Coordenação de Aperfeiçoamento de Pessoal de Nível Superior (CAPES) and Conselho Nacional de Desenvolvimento Científico e Tecnológico (CNPq).

\section{REFERENCES}

Brasil (1996). Portaria n. 11 de 12 de Abril de 1996. Estabelece Critérios Complementares para Classificação do Milho. Diário Oficial da União, Brasília, n. 72.

Cargnelutti Filho A and Storck L (2009). Medidas do grau de precisão experimental em ensaios de competição de cultivares de milho. Pesqui. Agropecu. Bras. 44: 111-117. https://doi.org/10.1590/S0100-204X2009000200001

Casa RT, Reis EM and Zambolim L (2006). Doenças do milho causadas por fungos do gênero Stenocarpella. Fitopatol. Bras. 31: 427-439. https://doi.org/10.1590/S0100-41582006000500001

Clements MJ, Kleinschmidt CE, Maragos CM, et al. (2003). Evaluation of inoculation techniques for fusarium ear rot and fumonisin contamination of corn. Plant Dis. 87: 147-153. https://doi.org/10.1094/PDIS.2003.87.2.147

Cruz CD (2013). GENES - A software package for analysis in experimental statistics and quantitative genetics. Acta Sci. Agron. 35: 271-276. https://doi.org/10.4025/actasciagron.v35i3.21251

Cruz CD and Regazzi AJ (2001). Modelos Biométricos Aplicados ao Melhoramento Genético. 2 ed. UFV, Viçosa, 2001. 390.

Dorrace AE and Hinkelmann KH (1998). Diallel analysis of diplodia ear rot resistance in maize. Plant Dis. 1: 699-703. https://doi.org/10.1094/PDIS.1998.82.6.699

Durrant WE and Dong X (2004). Systemic acquired resistance. Annu. Rev. Phytopathol. 42: 185-209. https://doi. org/10.1146/annurev.phyto.42.040803.140421

Gao X, Starr J, Göbel C, Engelberth J, et al. (2008). Maize 9-lipoxygenase ZmLOX3 controls development, root-specific expression of defense genes, and resistance to root-knot nematodes. Mol. Plant Microbe Interact. 21: 98-109. https:// doi.org/10.1094/MPMI-21-1-0098

Gorovits R, Akad F, Beery H, Vidavsky F, et al. (2007). Expression of stress-response proteins upon whitefly-mediated inoculation of Tomato yellow leaf curl virus in susceptible and resistant tomato plants. Mol. Plant Microbe Interact. 20: 1376-1383. https://doi.org/10.1094/MPMI-20-11-1376

Griffing BA (1956). Concept of general and specific combining ability in relation to diallel crossing systems. Aust. J. Biol. Sci. 9: 463-493. https://doi.org/10.1071/BI9560463

Genetics and Molecular Research 16 (3): gmr16039415 
Hung HY and Holland JB (2012). Diallel analysis of resistance to fusarium ear rot and fumonisin contamination in maize. Crop Sci. 52: 2173-2181. https://doi.org/10.2135/cropsci2012.03.0154

Kovács K, Kovács GJ and Mesterházy Á (1994). Expression of resistance to fusarial ear blight in corn inbreds and their hybrids. Maydica 39: 187-190.

Martin M, Miedaner T, Schwegler DD, Kessel B, et al. (2012). Comparative quantitative trait loci mapping for gibberella ear rot resistance and reduced deoxynivalenol contamination across connected maize populations. Crop Sci. 52: $32-$ 43. https://doi.org/10.2135/cropsci2011.04.0214

Matheson AC and Raymond CA (1986). A review of provenance X environment interaction. Its practical importance and use with particular reference to the tropics. Commonw. Forest. Rev. 65: 283-302.

Mendes MC, Von Pinho RG, Von Pinho EVR and Faria MV (2012). Comportamento de híbridos de milho inoculados com os fungos causadores do complexo grãos ardidos e associação com parâmetros químicos e bioquímicos. Ambiência 8: 275-292. https://doi.org/10.5777/ambiencia.2012.02.04

Mesterházy Á, Lemmens M and Reid LM (2012). Breeding for resistance to ear rots caused by Fusarium spp. In Maize - A Review. Plant Breed. 131: 1-19. https://doi.org/10.1111/j.1439-0523.2011.01936.x

Mohammadi M, Anoop V, Gleddie S and Harris LJ (2011). Proteomic profiling of two maize inbreds during early gibberella ear rot infection. Proteomics 11: 3675-3684. https://doi.org/10.1002/pmic.201100177

Mukanga M, Derera J, Tongoona P and Laing MD (2010). A survey of pre-harvest ear rot diseases of maize and associated mycotoxins in south and central Zambia. Int. J. Food Microbiol. 141: 213-221. https://doi.org/10.1016/j. ijfoodmicro.2010.05.011

Olatinwo R, Cardwell K and Menkir A (1999). Inheritance of resistance to Stenocarpella macrospora (Earle) ear rot of maize in the mid-altitude zone of Nigeria. Eur. J. Plant Pathol. 105: 535-543. https://doi.org/10.1023/A:1008734815796

Pimentel-Gomes F (2000). Curso de Estatística Experimental. 14. ed. Nobel, Piracicaba, 477.

Ramalho MAP, Abreu AFB, Santos JB and Nunes JAR (2012). Aplicações da Genética Quantitativa no Melhoramento de Plantas Autógamas. Universidade Federal de Lavras, Lavras, 522.

Reid LM, Zhu CX and Parker CA (2009). Increased resistance to Ustilago zeae and Fusarium verticillioides in Maize Inbred lines Bred for Fusarium graminearum resistance. Euphytica 165: 567-578. https://doi.org/10.1007/s10681$\underline{008-9782-6}$

Resende MDV and Duarte JB (2007). Precisão e controle de qualidade em experimentos de avaliação de cultivares. Pesqui. Agropecu. Trop. 37: 182-194.

Robertson LA, Kleinschmidt CE, White DG, Payne GA, et al. (2006). Heritabilities and correlations of fusarium ear rot resistance and fumonisin contamination resistance in two maize populations. Crop Sci. 46: 353-361. https://doi. org $/ 10.2135 /$ cropsci2005.0139

Silva E, Mora EA, Medina A, Vasquez J, et al. (2007). Fusarium ear rot and how to screen for resistance in open pollinated maize in the andean regions. Euphytica 153: 329-337. https://doi.org/10.1007/s10681-006-9171-y

Sprague GF and Tatum LA (1942). General vs. specific combining ability in single crosses of corn. Agron. J. 34: 923-932. https://doi.org/10.2134/agronj1942.00021962003400100008x

Tyagi S, Bratu DP and Kramer FR (1998). Multicolor molecular beacons for allele discrimination. Nat. Biotechnol. 16: 49-53. https://doi.org/10.1038/nbt0198-49

van Egmond HP, Schothorst RC and Jonker MA (2007). Regulations relating to mycotoxins in food: perspectives in a global and European context. Anal. Bioanal. Chem. 389: 147-157. https://doi.org/10.1007/s00216-007-1317-9

Wang W, Vinocur B, Shoseyov O and Altman A (2004). Role of plant heat-shock proteins and molecular chaperones in the abiotic stress response. Trends Plant Sci. 9: 244-252. https://doi.org/10.1016/j.tplants.2004.03.006

White DG (1999). Compendium of Corn Diseases. 3rd edn. APS Press. St. Paul, MN. 128. 